1963 (The Pollution of Water by Detergents. Pp. 86. Paris: Organization for Economic Co-operation and Development, 1964). The scope of the report can be judged by the number of references quoted--244. Subjects dealt with include tonnages and types of detergonts in present-day use, effects of pollution, analytical determination, and biological degradation. Administrative and technical measures which have been proposed for alleviation of the difficulties are also discussed. In view of the widespread interest in this topic the Organization for Economic Co-operation and Development recommended early publication, and there is some evidence of hasty preparation. Nevertheless, the authors and the Organization are to be congratulated on making available a publication which brings together a great deal of information, some of which was hitherto not readily available. The booklet should be of considerable value to all those concerned with the many aspects of this problem.

\section{Radiation Injury and Somatic Mutation}

THE first symposium in the Institute of Radiation Breeding in Japan was held during August 11-12, 1962. The Institute has a $\gamma$-field of $100 \mathrm{~m}$ radius with a cobalt-60 source in the centre. At present, crop and forage plants, vogetables, ornamental flowering plants, tea plants, fruit trees, mulberry trees and forest trees aro exposed in the field. These are used for investigations concerning differences in radiosensitivity between species and developmental stages, the effects of physiological and environmental conditions on sensitivity, the action of protective substances, and the production of germinal and somatic mutations. Population investigations on the irradiated soil micro-organisms and nematodes in the field have been initiated, and all ecological changes within and near the field will be monitored. The reports presented at the symposium, which have now been published, deal with modification of radiation-induced damage in seeds of rice and mulberry plants, differences in radiosensitivity between various stages of rice plants. the production of chlorophyll mutations in rice and of budsports in tulips and chrysanthemum (Radiation Injury and Somatic Mutation (Gamma Field Symposia, No. 1). Pp. 73. Ohmiya-machi, Tbaraki-ken, Japan: The Institute of Radiation Breeding, Ministry of Agriculture and Forestry, 1963). The data are discussed in relation to earlier work and in the framework of present-day theories on the action of radiation. The introductory paper is a clear and succinct outline of the biophysical aspects of radiation biology.

\section{Soil and Land-Use Survey of Jamaica}

The Regional Research Centre of the Imperial College of Tropical Agriculture was set up in 1955 and the Soils and Survey Section has beon engaged in an investigation of the main soil types with "a broad interpretation of the results in terms of land-usage and land-capability". Report No. 14, prepared by J. Stark, concerns the parish of St. Elizabeth in south-west Jamaica (Pp. $30+2$ soil maps on scale $1: 50,000$. Trinidad: Imperial College, 1963. 15s.). The salient features of this area of some 474 square miles, which have influenced soil development, are describod. The average daily temperatures range from about $60^{\circ}$ to $90^{\circ} \mathrm{F}$, the rainfall figures for around 40 years show averages of 40-100 in. for nino places, but torrontial rain during thunderstorms is much less valuable than the figures would indicate, and irrigation is beneficial in the southern districts. The geolcgy and lithology are discussed under such headings as alluvium (including morass, basin deposits and coastal sandstone), limestone formations, Trappean series of highly weathered shales, tuffs and conglomerates, and undifferentiated cretaceous shales. The relief and drainage are closely rolated to the geological pattern; the White Limestone Mountains rising to $2,500 \mathrm{ft}$. have pronounced dry valleys, while saline ponds are found at parts of the coast. Parent material is the most important factor in the formation of the soils, which have been classified in a manner convenient for the discussion of capability classes and recommended cultivation practices. Apart from some evergreen forest of tall trees in inaccessiblo places and mangrove swamp, thero is little natural vegetation left. Introduced plants such as breadfruit, bamboo, almond tree (Terminalia catappa) and various pasture grasses are of great importance. Bnef cattle are the most important livestock, and sugar cane the most important cultivated crop, but a large variety of fruits, vegetables and cereals is grown. Misuse of land in the past, through fragmentation by inheritance and subsistence farming, has greatly intensified erosion, and efforts are being directed to a more suitable land-use policy.

\section{Archæology in Switzerland}

Ciba Chemicals, Ltd., which has its headquarters at Basle, and a branch factory at Duxford in Cambridgeshire, issues a Journal from time to time. The winter $1963 / 64$ issue of the Ciba Journal contains two interesting archrological articles, one concerning the treasure of Kaiseraugst, by Prof. Rudolf Laur-Belort, and the other dealing with the well-known Mildenhall Treasuro. Basle, once the site of a Roman encampment, stands near where the Imperial legions defended the Rhenish frontier. Recently a find of silverware dating from those days has come to light nearby. The Mildenhall treasure is of a somewhat similar kind and age. The latter has been already well published some little time ago, but the two articles in the Ciba Journal are well illustrated and so comparisons of the two finds can easily be made.

\section{Early Farmsteads in French Canada}

A RECENT publication of the National Museum of Canada describes in detail some of the early farmsteads of Quebec (Ministère du Nord Canadien et des Ressources Nationales. Bulletin No. 192 (No. 2 de la Série des Bulletins d'Histoire): Les Granges du Québec du XVII au $X I X^{\mathrm{e}}$ Siècle. Par Robert-Lionel Séguin. Pp. viii +128 (60 planches). Ottawa: Imprimeur de la Reine, 1963. 2.50 dollars). The rural buildings of Quebec fitl under two main headings: the poorer dwelling with a barn attached, and the more elaborate house with an inner yard surrounded by farm buildings. A detailed examination of some of these buildings demonstrates the basic similarities to Western French rural traditions, but in French Canada local climatic and economic conditions have resulted in regional styles, including the adaptation of Indian techniques. A study of the history of rural building construction in Quebec shows that the 'bees' aro mainly a ninetoenth-century innovation. This wellillustrated bulletin is a useful source of information for anyone interested in carly building techniques and their organization.

\section{University News :}

Belfast

Dr. A. A. Weurs has been appointed to the chair of structural science (a second chair in the Department of Civil Engineering). Dr. F. J. Wallace has been appointed to the chair of thermodynamics and fluid mechanies (a. second chair in the Department of Mechanical Engineering). L. H. Tanner has been appointed to a senior lectureship in aeronautical ongineering. Dr. J. R. M. Coulter and Dr. B. S. Cox have been appointed to lectureships in physies and geneties, respectivoly.

Birmingham

THe following appointments have been made: Lecture. ships, Dr. C. A. Barson and Dr. J. N. Hay (chemistry); Dr. D. E. Briggs (biochemistry in the Sub-Department, of Malting and Brewing); Dr. D. J. Candy and Dr. A. A. Horton (biochemistry); Dr. E. Canel (mathematical physics); Dr. C. E. Gough (physies); P. J. C. Child, 